\title{
Nonparametric economic analysis of the level of technical efficiency of cattle meat production in the Krasnodar Krai in 2013-2018
}

\author{
Aleksandr Sayfetdinov ${ }^{1,{ }^{*}}$, and Polina Sayfetdinova ${ }^{1}$ \\ ${ }^{1}$ Kuban State Agrarian University named after I.T. Trubilin, Russia
}

\begin{abstract}
Calculations of estimates of the technical efficiency of production activities of agricultural organizations of the Krasnodar Krai that produce live weight gains of cattle in 2018 were performed. For this purpose, a nonparametric method is used, which compares the actual and potentially possible maximum production volumes calculated using the linear programming method for each specific commodity producer in a representative sample of enterprises and forming a broken boundary production function. The size of the potential for growth in the production of meat cattle products based on the existing livestock in the region was determined and priority areas for its implementation was identified. It was established that the main factors hindering the development of meat cattle breeding in the Krasnodar Krai are low potential of biological productivity of the livestock breeds used, use of unbalanced feed rations that lead to a large overspend of certain types of feed, and low labor productivity.
\end{abstract}

\section{Introduction}

In recent years, the domestic economy has been operating in a difficult micro- and macroeconomic environment under the influence of tough sanctions imposed by the Western nations, reinforced by instability in the global hydrocarbon markets and the consequences of a global pandemic that hinders the development of the world economy as a whole. At the same time, agriculture is one of the few industries that has shown mostly positive results in these years, with a noticeable increase in the volume of domestic production of most types of agricultural products, which was largely facilitated by the domestic food embargo imposed by our country in response to Western sanctions. At the same time, there are still many unresolved problems in domestic agriculture related to low labor productivity and technical and technological backwardness of production.

The situation is particularly difficult in the domestic beef cattle breeding [1,2]. Currently, in the structure of the cattle population in Russia, the share of animals of specialized meat breeds does not exceed $10 \%$, which mainly hinders the development of the sub-sector. Agricultural producers using dairy breeds with a lower biological potential of meat productivity for fattening animals cannot provide high gains in livestock at all stages of their raising, and the taste of the resulting final product turns out to be low. The unprofitability of beef cattle breeding hinders

*Corresponding author: saifet@mail.ru 
investment attraction, and the existing measures and volumes of state support are insufficient and cannot significantly increase investment attractiveness and ensure expanded reproduction in the sub-sector. All this leads to a constant decrease in beef consumption in Russia with its displacement from the diets of the population by cheaper types of meat. The purpose of this article is to determine the level of technical efficiency of cattle meat production in the Krasnodar Krai and justify the priority areas for its improvement.

\section{Materials and methods}

The technical efficiency of agricultural production is determined by the available resource potential and the degree of its use with the use of innovative technologies, which is manifested in the production of products in the maximum possible volumes with minimal specific resource costs.

To estimate the level of technical efficiency of cattle meat production in the agricultural organizations of the Krasnodar Krai the technique was used that allows one to determine the level of use of the resource potential of specific commodity producers and the industry as a whole, as the ratio of the actual and maximum possible within the given resource constraints, production volumes, calculated from the results of activities of leading agricultural organizations in considered representative sample. The activity of agricultural producers will be effective if these actual and maximum possible production volumes coincide [3-6].

Let the operational activity of a group of $k$ producers for the time period under study be described by the set $P=\left\{\boldsymbol{x}_{i}, \boldsymbol{y}_{i} \mid t=1, \ldots, k\right\}$, where $\boldsymbol{x}_{i}=\left(x_{i 1}, \ldots, x_{i n}\right)-$ vector of expenditure volumes of $n$ production resources of the $i$-th commodity producer $\left(\boldsymbol{x}_{i} \in \mathfrak{R}^{n+}\right) ; y_{i}$-volume of production by the $i$-th commodity producer $\left(y_{i} \in \mathfrak{R}^{n+}\right)$.

Then the potential production volumes for each $i$-th commodity producer can be determined by solving the following linear problem [7-10]:

$$
\sum_{i=1}^{k} y_{i} \lambda_{i} \rightarrow \max _{\lambda=\left(\lambda_{1}, \ldots, \lambda_{k}\right)} ;\left\{\begin{array}{l}
\sum_{i=1}^{k} x_{i j} \lambda_{i} \leq x_{j}, \forall j ; \\
\sum_{i=1}^{k} \lambda_{i}=1 ; \\
\lambda_{i} \geq 0, \forall i,
\end{array},\right.
$$

where $\lambda=\left(\lambda_{1}, \ldots, \lambda_{k}\right)-$ vector of non-negative "weights".

The level of technical efficiency of the production activity of the $i$-th commodity producer will be calculated as the quotient of dividing the actual production volumes $y_{i}$ by the maximum possible volumes determined by the solution of problem (1) for the given resource constraints.

\section{Results and discussion}

The initial statistical information for the analysis was the data of the annual financial and economic reports of agricultural organizations of the Krasnodar Krai that produce live weight gains of cattle in 2018.

In 1990-2018, in agricultural organizations of the Krasnodar Krai, the number of cattle decreased by more than 3 times, and the volume of meat production of this type of animal decreased by half (table 1). 
Table 1. Main production and economic indicators of meat and dairy cattle breeding in the Krasnodar Krai

\begin{tabular}{|c|c|c|c|c|c|}
\hline Indicators & 1990 & 2000 & 2010 & 2018 & $\begin{array}{l}2018 \text { in } \% \\
\text { to } 1990\end{array}$ \\
\hline $\begin{array}{l}\text { Livestock of cattle, thousand } \\
\text { heads }\end{array}$ & 1778.1 & 920.6 & 649 & 533.2 & 30.0 \\
\hline $\begin{array}{l}\text { Produced, thousand tons: } \\
\text { increase in live weight of cattle } \\
\text { milk }\end{array}$ & $\begin{array}{c}249.6 \\
2065.5\end{array}$ & $\begin{array}{c}108.3 \\
1270.6\end{array}$ & $\begin{array}{c}122.2 \\
1396.7\end{array}$ & $\begin{array}{c}119.5 \\
1449.8\end{array}$ & $\begin{array}{l}47.9 \\
70.2\end{array}$ \\
\hline $\begin{array}{l}\text { Average daily weight gain of } \\
\text { cattle for fattening and growing, } g\end{array}$ & 488 & 437 & 619 & 714 & 146.3 \\
\hline $\begin{array}{l}\text { Milk produced per cow per year, } \\
\mathrm{kg}\end{array}$ & 3558 & 3194 & 5419 & 7775 & 2.2 times \\
\hline $\begin{array}{l}\text { Average profitability (loss) of } \\
\text { sales, \%: } \\
\text { live weight of cattle meat } \\
\text { milk }\end{array}$ & $\begin{array}{l}\mathrm{n} / \mathrm{a} \\
\mathrm{n} / \mathrm{a}\end{array}$ & $\begin{array}{l}-36.0 \\
-6.2 \\
\end{array}$ & $\begin{array}{l}-25.8 \\
20.4\end{array}$ & $\begin{array}{c}-33.2 \\
16.7\end{array}$ & $\begin{array}{l}- \\
-\end{array}$ \\
\hline
\end{tabular}

In the Krasnodar Krai, meat cattle breeding is organized mainly on the basis of fattening dairy animals, which have a share in the total population of more than $90 \%$. The average daily weight gain of cattle for growing and fattening in agricultural organizations in the region in 2018 was $714 \mathrm{~g}$, which is significantly higher than the same indicator in 2000, but almost twice lower that the level of advanced enterprises that effectively organized the fattening of livestock of specialized meat breeds.

Currently, in the Krasnodar Krai, specialized meat cattle breeding is organized in 31 agricultural organizations, which contain 23.7 thousand heads of animals. At the same time, only in six organizations, commodity producers managed to ensure a positive profitability of production activities, equal to an average of $10-15 \%$.

The estimation of technical efficiency of production of live weight gains of cattle was performed according to a representative sample of 100 agricultural organizations that produce cattle meat on the basis of fattening dairy animals. Correct application of the method (1) is possible only for enterprises that use the same production technology. Therefore, organizations that raise and fatten beef cattle using a specialized technology, including receiving calves, feeding them according to the "cow-calf" system, further growing and final fattening using large volumes of concentrated feed, were excluded from the considered sample.

Annual production volumes $\left(y_{i}\right)$ in each agricultural organization were calculated as the sum of the live weight of the calf crop received and the live weight gains of livestock at all stages of its cultivation and fattening. As independent variables $\left(x_{i}\right)$, which largely determine the volume of production of final products, the live weight of the existing livestock of cattle at the beginning of the year (c); live weight of purchased livestock (c); labor costs during the year (people-hours); costs of electricity $(\mathrm{kWh})$ and petroleum products (c); consumption of veterinary drugs (l) and feed (c.u.); maintenance of fixed assets (thousand rubles) were used.

One of the most important factors in the efficiency of production of cattle live weight gains is the use of optimal animal feeding diets, balanced in all nutritional elements and vitamins. Feed consumption in physical terms for each agricultural organization included in the considered representative sample was calculated as a quotient of the monetary cost of feeding animals in all gender and age groups by the average cost of $1 \mathrm{c}$.u. of the feed.

The efficiency of production activities in beef cattle breeding also largely depends on the quality, safety and timely use of veterinary drugs for the prevention and rapid treatment of various animal diseases, which ensures the safety of livestock and allows to get large increases in live weight. The consumption of veterinary drugs in physical terms was 
determined as the quotient of the division of the cost of their purchase and use in each agricultural organization by the weighted average cost of their main types used in the subsector.

Similarly, the costs in physical terms of other production resources in the meat cattle breeding of the Krasnodar Krai were determined.

Table 2 shows the results of calculations of the technical efficiency of production of live weight gains of dairy cattle in agricultural organizations in the region in 2018, as well as the results of similar calculations for the group of enterprises under consideration using information about their production activities in 2013 [9].

Table 2. Generalized results of evaluation of technical efficiency of cattle meat production in agricultural organizations of the Krasnodar Krai in 2013 and 2018.

\begin{tabular}{|l|c|c|c|}
\hline \multirow{2}{*}{\multicolumn{1}{|c|}{ Indicators }} & \multicolumn{2}{c|}{$\begin{array}{c}\text { Technical efficiency } \\
\text { estimations }\end{array}$} & \multirow{2}{*}{$\begin{array}{c}\text { Change of } \\
\text { indicators }\end{array}$} \\
\cline { 2 - 3 } & $\mathbf{2 0 1 3}$ & $\mathbf{2 0 1 8}$ & \\
\hline Maximum value by group of companies & 1 & 1 & 0 \\
\hline Minimum value by group of companies & 0.33 & 0.39 & +0.06 \\
\hline Arithmetic average & 0.75 & 0.88 & +0.13 \\
\hline $\begin{array}{l}\text { Weighted average value (by volume of } \\
\text { production) }\end{array}$ & 0.80 & 0.93 & +0.13 \\
\hline Standard deviation & 0.22 & 0.16 & -0.06 \\
\hline
\end{tabular}

The calculations performed showed that the weighted average of estimated technical production efficiency in beef cattle in the Krasnodar Krai in 2018 amounted to 0.93, which indicates the existence of potential of growth of production volumes of cattle meat based on the available livestock breeds without significant transformation of the technology used and the resource base. Thus, only by increasing the technical efficiency of producers, it is possible to increase the volume of production of cattle meat in the region by about $7 \%$. At the same time, in 2013-2018, agricultural producers managed to increase the technical efficiency of their production activities by an average of 0.13 , which partially compensated for a significant decrease in livestock and prevented the same collapse in the volume of cattle meat production in the region.

About $36 \%$ of the organizations included in the representative sample provided full technical efficiency of their activities in 2018, while in four organizations their estimates were less than 0.5 (table 4 ).

Table 4. Group of agricultural organizations in the considered representative sample by the level of technical efficiency of production activities, 2018

\begin{tabular}{|l|c|c|c|c|c|c|}
\hline \multirow{2}{*}{ Indicators } & \multicolumn{4}{|c|}{$\begin{array}{c}\text { Groups of organizations with technical efficiency of } \\
\text { production activities: }\end{array}$} & \multirow{2}{*}{$\begin{array}{c}\text { On } \\
\text { average }\end{array}$} \\
\cline { 2 - 6 } & $\begin{array}{c}\text { less than } \\
0.5\end{array}$ & $0.51-0.7$ & $0.71-0.9$ & $0.91-0.99$ & 1 & 100 \\
\hline $\begin{array}{l}\text { Number of companies in } \\
\text { the group }\end{array}$ & 4 & 12 & 30 & 18 & 36 & 0.930 \\
\hline $\begin{array}{l}\text { Weighted average of } \\
\text { technical performance } \\
\text { ratings in the group }\end{array}$ & 0.390 & 0.629 & 0.804 & 0.949 & 1.000 & 8.4 \\
\hline $\begin{array}{l}\text { Average feed consumption } \\
\text { per 1 kg of live weight gain } \\
\text { of cattle, c.u. }\end{array}$ & 12.9 & 9.8 & 8.5 & 8.3 & 7.4 & 0.12 \\
\hline $\begin{array}{l}\text { Average labor costs per 1 } \\
\text { kg of increase in live } \\
\text { weight of cattle, people- } \\
\text { hour }\end{array}$ & 0.27 & 0.19 & 0.17 & 0.13 & 0.09 & \\
\hline
\end{tabular}


In the first group of agricultural organizations with the lowest technical efficiency of production activities, there is a large specific feed consumption, in which their conversion is on average 12.9 c.u. per $1 \mathrm{~kg}$ of live weight gains of livestock, as well as the lowest labor productivity. At the same time, with the growth of technical efficiency estimations in the representative sample under consideration, these specific production indicators noticeably improve and amount to $7.4 \mathrm{c} . \mathrm{u}$. and $0.09 \mathrm{p}$-h. per $1 \mathrm{~kg}$ of manufactured products in group 5, respectively.

\section{Conclusions}

In the Krasnodar Krai, the number of cattle is continuously decreasing, and at the same time, the volume of meat production of this type of animal is decreasing. To determine the level of technical efficiency of production activities in the meat cattle breeding of the Krasnodar Krai, a nonparametric method was used, which compares the actual and potentially possible production volumes, which are calculated using the linear programming method for each specific commodity producer in a representative sample of enterprises and form a broken boundary production function.

The obtained estimations of the technical efficiency of agricultural organizations engaged in the production of live weight gains of dairy cattle in the Krasnodar Krai in 2018 vary quite widely with a weighted average value of 0.93 . This means that the potential for growth in the production of cattle meat based on the existing livestock in the region is approximately $7 \%$. Comparative calculations showed that in 2013-2018 the technical efficiency of meat cattle breeding in the region increased from 0.8 to 0.93 on average, which partially compensated for the negative consequences of the decline in the number of animals of this species.

For further improvement of technical efficiency in this sub-sector, it is important for producers to improve the feeding of animals in all gender and age groups by using optimal feed rations that are balanced by all nutrients and vitamins, as well as to increase labor productivity by improving all production processes with their mechanization and automation.

\section{Acknowledgements}

The research was carried out with the financial support of the RFBR and the Krasnodar Krai in the framework of the scientific project No. 19-410-233007.

\section{References}

1. A. Tikhomirov, Economy of Russia agriculture, 1, 76-84 (2018)

2. V.I. Chinarov, N.I. Strekozov, V.A. Chinarov, Dairy and beef cattle breeding, 7, 16-19 (2017)

3. Yu.I. Bershitsiy, N.R. Saifetdinova, K.E. Tyupakov, N.K. Vasilieva, E.I. Artemova, International Journal of Applied Business and Economic Research, 14(10), 7267-7287 (2016).

4. V. Ceyhan, K. Hazneci, Journal of animal and veterinary advances, 9. 60-69 (2010)

5. D.J. Otieno, L. Hubbard, E. Ruto, Technical efficiency and technology gaps in beef cattle production systems in Kenya: A stochastic metafrontier analysis, The 85th annual Conference of the Agricultural Economics Society (AES), (2011)

6. A.N. Rakipova, J.M. Gillespie, D.E. Franke. Journal of the ASFMRA, 99-107 (2003) 
7. S.N. Afriat, International economic review, 3, 568-596 (1972)

8. Y.I. Bershitskiy, A.R. Sayfetdinov, Complex Systems:Innovation and Sustainability in the Digital Age, 297-306 (2019)

9. Y.I. Bershitskiy, M.F. Safonova, A.R. Sayfetdinov, Espacios, 40(10) (2019)

10. T.J. Coelli, Australian Journal of Agricultural Economics, 3, 219-245 (1995) 